\title{
OPTIONS OF SUPPORT FOR PRIMARY SCHOOLS' PUPILS WITH MENTAL DISABILITIES WITH HIGHLIGHTS ON SOCIAL AND EDUCATIONAL ASPECTS IN THE CZECH REPUBLIC
}

\author{
OPÇÕES DE APOIO A ALUNOS DE ESCOLAS PRIMÁRIAS COM DEFICIÊNCIA \\ MENTAL COM DESTAQUE NOS ASPECTOS SOCIAIS E EDUCACIONAIS NA \\ REPÚBLICA TCHECA
}
OPCIONES DE APOYO PARA ALUMNOS DE ESCUELAS PRIMARIAS CON DISCAPACIDAD MENTAL CON ASPECTOS DESTACADOS SOBRE ASPECTOS SOCIALES Y EDUCATIVOS EN LA REPÚBLICA CHECA

\author{
Lukáš STÁREK ${ }^{1}$ \\ Jarmila KLUGEROVÁ2 \\ Marie KOCUROVÁ ${ }^{3}$
}

\begin{abstract}
This paper focuses on legal and inclusive changes in Czech's primary schools' environment. Since 2016 Czech's primary schools are including in the education of more pupils with intellectual disability. The following text is introducing the tools which support the idea of common education such as supportive adjustments, use of assistive services. Furthermore, it presents a reflection of this modern approach from perspectives of special pedagogy and social work.
\end{abstract}

KEYWORDS: Environment. Inclusion. Intellectual disability. Support. Pupil.

RESUMO: Este artigo enfoca as mudanças legais e inclusivas no ambiente das escolas primárias checas. Desde 2016, as escolas primárias checas estão a incluir na educação mais alunos com deficiência intelectual. O texto a seguir apresenta as ferramentas que apoiam a ideia de educação comum, como ajustes de suporte e uso de serviços de assistência. Além disso, apresenta uma reflexão desta abordagem moderna a partir de perspectivas de pedagogia especial e serviço social.

PALAVRAS-CHAVE: Ambiente. Inclusão. Deficiência intelectual. Suporte. Aluno.

RESUMEN: Este documento se centra en los cambios legales e inclusivos en el entorno de las escuelas primarias checas. Desde 2016, las escuelas primarias checas están incluidas en la educación de más alumnos con discapacidad intelectual. El siguiente texto presenta las herramientas que respaldan la idea de educación común, como ajustes de apoyo, uso de

${ }^{1}$ Jan Amose Komenský University (UJAK), Prague - Czech Republic. Ph.D, Department of Special Education. ORCID: https://orcid.org/0000-0002-6068-215X.E-mail: starek.lukas@ujak.cz

2 Jan Amose Komenský University (UJAK), Prague - Czech Republic. Ph.D, Department of Special Education. ORCID: https://orcid.org/0000-0002-7174-3704. E-mail: klugerova.jarmila@ujak.cz

${ }^{3}$ Jan Amose Komenský University (UJAK), Prague - Czech Republic. Ph.D, Department of Special Education. ORCID: https://orcid.org/0000-0002-8907-8140. E-mail: kocurova.marie@ujak.cz

RPGE- Revista on line de Política e Gestão Educacional, Araraquara, v. 25, n. 3, p. 2552-2566, Sep./Dec. 2021. e-ISSN: 1519-9029 DOI: https://doi.org/10.22633/rpge.v25i2.15841 
servicios de asistencia. Además, presenta un reflejo de este enfoque moderno desde perspectivas de pedagogía especial y trabajo social.

PALABRAS CLAVE: Medio ambiente. Inclusión. Discapacidad intelectual. Apoyo. Alumno.

\section{Introduction}

The educational policy in the Czech Republic is focused on the development of the educational system which places education at the forefront of concerns of both society and individuals. Education is understood as the significant values that one is cultivating over their whole life. Quality education should be accessible for all; thus, everyone has the same chance for a better life. At each level of education, it is crucial for pupils to know what is expected from them and what they can expect from education. Education rests on current human understanding, supports creativity and accommodates society's needs. One accumulates knowledge throughout their whole life and their interest in education is supported by experienced educational staff. The staff should be properly prepared for their role, and they should be able to lead and motivate the pupils to achieve their utmost in set goals with regards to the social trend toward inclusion in education.

The integration of individuals with a disability into a society of equal opportunity has become the main aim of special-needs pedagogy (VÍTKOVÁ, 2004). Inclusion is the concept that supports the integration of individuals with a handicap. This term is understood as the integration of individual pupils into schools in the educational mainstream. It stems from the remorse for labelling and stigmatisation and intends to end special-needs institutions and special-needs pedagogy (BARTOŇOVÁ, 2017). The primary goal of inclusion involves the collective education of individual pupils in "ordinary" schools without regards to the level of their disability (HÁJKOVÁ; STRNADOVÁ, 2010).

The label of inclusive education has recently been used for many activities and procedures, which could lead to misunderstandings. Inclusive education can be judged as the preserve of education policy in the Czech Republic. It is crucial to recognise what creates inclusion, i.e., attempts at change, and alternative methods and forms of work. A very sensitive aspect of the process of inclusive education is the moral side, the right of each society member to have equal access to education, and financial support of inclusive education also. These are the crucial aspects of introducing inclusive education in practice (CLOUGH; CORBETT, 2005). 
In the scope of inclusive education, the family must be mentioned, both from the perspective of the environment where a child/pupil lives and that influences them and from the perspective as a partner of an educational institution. Communication, trust and respect are areas that ensure the effectiveness of cooperation between the school and family. The parents, and possibly even the school, share a common responsibility in the process of raising and teaching a child, and without cooperation, it is not possible to ensure a positive influence on him or her (STÁREK, 2021).

\section{The compulsory education of pupils with intellectual disability}

In the Czech Republic, compulsory primary education is for 9 years. After finishing compulsory preschool education - one year of preschool services, compulsory primary education follows. Primary compulsory education is compulsory for everyone without a difference, thus for pupils with any level of intellectual disability also. Compulsory primary education starts at 6 years of age. There is the possibility for the delay on one condition - that a child with a delay begins its education later during the academic year when they reach 8 years. Therefore, a pupil can complete compulsory primary education by the age of 17 . However, based on the legal guardians' request, a headmaster can postpone completion until a pupil turns 18. Nevertheless, another exception can be made for pupils with a disability, who can have their graduation postponed until they are 20. Furthermore, based on the decision of the head of the educational institution the completion of compulsory education for pupils with a medium intellectual disability, high intellectual disability, multiple disabilities, and autisms can be postponed until they are 26 (BEDNOVÁ, 2012).

In recent years, the society aims to educate children with a mild intellectual disability at "ordinary" primary schools. Therefore, the children with a mild intellectual disability become pupils with special education needs. The pupils with an intellectual disability have two options when they start compulsory primary education. The first option is to be integrated into primary school with pupils without disability or be educated in special primary school.

\section{The primary school}

The commencement of compulsory primary school is an important milestone for the life of every child. The child assumes a new role as a pupil and, with the role, his/her social prestige grows. At an "ordinary" primary school a child obtains the first impressions of 
classmates and teachers towards a child's disability. A child does not only encounter a positive attitude toward their disability, especially from classmates (VÁGNEROVÁ, 2000). The success of integration depends on many factors such as support of legislative norms, and positions of family, schools and counselling services. Every child has the right to be educated and must be afforded the opportunity to reach an accessible level of education.

Primary education results in pupils familiarising themselves with fundamental learning strategies and becoming motivated for life-long learning. Also, it teaches them to think creatively, solve adequate problems, effectively communicate and cooperate. Another aim of primary education is to teach children to actively protect their physical health and wellbeing. It provides them with the basis of values and life principles. Another aim is to teach the pupils to be tolerant and respectful towards people with different ethnicity, faith, values and beliefs. Finally, the aim is to teach pupils to recognise their possibilities and skills and teach them how to use their knowledge and skills in their further life (MİCHALÍK, 2003).

With regards to statistics, an endeavour is evident in the Czech Republic to make inclusive education widespread. It is not only children with a mild intellectual disability whose parents decided to integrate and educate them in "ordinary" primary school. The number of pupils with a mild intellectual disability in primary schools is growing, according to the Statical Yearbook for 2016-2017 (MINISTTERSTVO ŠKOLSTVÍ, 2020). During the 2016/2017 academic year, 3,780 pupils with a mild intellectual disability attended primary schools. In the 2019/2020 academic year, the number of these pupils grew to 4,855 .

According to Section 16, paragraph 9 of the Education Act, education at the first stage follows the framework educational program for primary school and is regulated in the school educational program. The pupils at the second stage finish their education based on the Educational Framework Program for Primary Education - the appendix regulating the education of pupils with a mild intellectual disability, again regulated in the school educational program. During the 2019/2020 academic year, this education of pupils with a mild intellectual disability is put into practice. The process of teaching and raising the pupils is modified for their needs and skills (VÍŠEK, 2020).

Another important aspect is a legal perspective, the modern tendencies in the history of democratic and legal states are presenting requirements for residents to be an active part in the production of a legally stable and solid environment in relation to primary human right and liberties. The solid democratic states create complicated legal rules and systems to be able to guarantee safe and fair use of human right and liberties. Also, to guarantee fulfilment of legal responsibilities. 


\section{Support measures and training}

Support measures are mainly for pupils with special education needs and they are supporting pupils with fulfilling their educational potential. Most pupils are using the support measures because they have health disability, lifelong illnesses or pupils are from an unstimulating social environment, or they are immigrants. To receive support measures can a pupil in primary school and the special school also (BARTOŇOVÁ, 2013).

They are different types of support measures for all sort of pupils i.e., pupils with intellectual disability and weaker in cognitive development, pupils with social disadvantage, pupils with an autistic spectrum disorder or diverse psychological illnesses, pupils with a physical disorder or serious illnesses, pupils with visual disorder or weaknesses in a visual sense, pupils with a hearing disorder or weaknesses in hearing sense, and pupils with problematic communication.

The level of support measures and educational need for the concrete pupil is assigned based on several (special)pedagogical, psychological diagnosis done by the school's counselling services or special pedagogical centre. The support system and its work are focused on providing support to a pupil who needs to equal their disadvantage in the diverse situation. The support system includes these fields of support:

Organization of education, the support provided to pupils who are easily and quickly tired, unfocused, non-independent while working, have problems understanding topic. During teaching pupils with intellectual disability and weaker cognitive development is important to have a calm atmosphere in the classroom, a lower number of pupils in the classroom, respect for individual pace, pupils' easier tiredness and short-time focus. Suitable for this type of pupils is often changing form of work, relax with activity, switching the working place i.e., table, rug. If there is a teacher assistant in the class a pupil can leave the classroom while a lesson to switch place.;

- Modification of educational methods and forms of work, the support is provided to pupils with lower ability to focus, with lower intellectual, communicational, and perception ability, to pupils lower working pace, to unsuccessful long-term pupils, to pupils unable to meet the expectation of a pedagogue while frontal education, to pupils who do not understand to the topic, to pupils who are not motivated to work, to pupils with ADHD or ADD, to emotionally unstable pupils, to pupils with impulsivity, to pupils with behavioural disorders, or to pupils who are excluded from the class collective.; 
- Intervention, the support is provided to pupils who have problems while education, to pupils with a diagnosis of behavioural disorder, to pupils with communicational problems, and to pupils with problems to understand speech and communication. Furthermore, the support is offered to pupils who have problems with attention and memory, who have limited vision or hearing perception on the cognitive base (ability to process the stimulus), who have problems with understanding instructions and recalling information, who quickly forget, who cannot finish their work and cannot focus. These pupils have problems with orientation in the schools and their surroundings, their self-care abilities are lower developed, and they tend to close themselves. They have problems with aggression, auto aggression, destructive and disruptive behavioural, and problematic behavioural can appear due to their lower ability to communicate also.;

Tools, support is offered to pupils with limited ability to focus, lower cognitive abilities, slower pace, lower knowledge of the used language. A pupil has lower motorial and perception skills, they have diagnosed higher level of intellectual disability (VALENTA et al., 2015).

Modification of content, the modification is offered to pupils with lower intellectual ability, weaker cognitive functions and lower adaptability, pupils with sense disability and limited ability to move, pupils who are healthily disadvantaged, or to pupils with long-term absence.

- Classification, support is offered to pupils who cannot fulfil the school's requirements due to their weaker cognitive accomplishment. The classification takes into account pupils' abilities which are based on their achieved level of cognitive level (VALENTA et al., 2015).

- Preparation for education, support is provided to pupils who are not able to achieve the required level of education in school, who need more time for accommodating the information, and whose parents are not able to secure home preparation for a pupil (VALENTA et al., 2015).

- Social and health support is focused on health support, food support and its connection to social services and others.;

Work with the class collective, support is provided to pupils who have problems with making social connections in-class collective, or to a pupil who cannot predict consequences of their behaviour, The important requirement for success is knowledge of the class collective, family environment, and ability to predict risk situations. It is crucial to set up 
rules and their following, the risk situation can be simulated and practised also (VALENTA et al., 2015).

Adjustment of environment, this process is done only when a pupil cannot work and use their working place, has problems with concentration, and cannot organize their school life (VALENTA et al., 2015).

\section{The context of support measures for pupils with intellectual disabilities}

The support measures are defined in Czech legislation, namely Act No. 82/2015 Coll (CZECH REPUBLIC, 2015), which amends Act No. 561/2004 Coll. (CZECH REPUBLIC, 2004), on Preschool, Primary, High, Higher Specialised, and Other Education and in Decree No. 27/2016 Coll. (CZECH REPUBLIC, 2016) on the Education of Pupils with Special Education Needs and Gifted Pupils. The support measures are grounded in the counselling assistance of a school and school counselling office. With regards to the recommendation from the counselling office, several features have been amended: organisation of content, evaluation, form and methods of education and school services. The changes include the safeguarding of teaching the subject of special pedagogical care and prolonging of the study period either high school or higher specialised education for two years. Furthermore, the conditions of acceptance and conditions of ending the education are also amended. Also, the use of compensatory aids, specialised textbooks and special teaching aids, use of communication systems for deaf and deaf-blind students are defined, and the expected learning outcomes of the study with regards to the educational framework programs and accredited educational programs will be adjusted. They also stipulate the possibilities of education according to individual educational plans, the help of a teacher assistant or another teaching professional (interpreter, transcriber etc).

The range of disability severities requires a corresponding range of support measures, so the results can be most suitable for a pupil and the best possible outcomes can be met. The support measures are divided into five main categories based on organisational, pedagogical and financial difficulty. The support measures can be combined. The support measures are used chronologically, so the highest provisions are used after the lower provisions are insufficient and the pupil is not able to meet the requirements. Inclusion in support measures is provided for by a statutory instrument. The support measures of the first level can be applied by the school on its own. However, the support measures from the second to the fifth level can be applied only by recommendation of counselling service. The condition of 
applying the support measures from the second to the fifth level is the agreement of an adult pupil or his/her legal guardian. If the support measures from the second to the fifth level are not needed, the school can cease offering them after consultation with the pupil's legal guardian.

The aim of the first level of support measures is to apply the common method of work, which can act as prevention against the pupil's poor performance at school. "The support measures of the first level present the minimal adjustment of the methods, organisation and evaluation of education. They are offered to a pupil who needs adjustment in education or school services or integration in the collective. The first level support measures are not financially demanding. If the first level supportive provisions did not meet the needs of a pupil, the school or educational institution (further school) would offer the pupil use of school counselling with the aim of assessing their special educational needs. The correct implementation can result in stabilisation of performance and may prevent repeated school failure, aversion to education and falling to lower levels. The support measures identify teachers with regards to knowing the pupil. They can analyse his/her work by monitoring $\mathrm{him} / \mathrm{her}$ in class, through long-term evaluation and knowledge of his/her health as well as their family and social situation. This knowledge leads to possibly identifying the causes of failure and tabling those measures that will prevent educational issues in the future. The support for pupils is provided by teachers after consultation with their colleagues from the counselling service. The adjustment of educational content does not have any influence on the level of results. It is useful to cooperate with classmates or parents, mainly during the home preparation for school. The usual materials are used (MICHALÍK, 2015).

The second level of support measures requires the provision of those special-needs teaching methods that a teacher is able to use without interrupting the educational process of other pupils. It is ideal to include a pupil in collective education. These measures are implemented on the recommendation of school counselling services, which are defined by the counsellor. Most often, these measures include the change in seating positions, adjustment of the length of a lesson and breaks, setting up a specific work focused on the use of vision and hearing, and creation of diverse working limits for a pupil. The lessons take place with the rest of the class, but with the individual attention of a teacher to the pupil and problematic topics. If it is needed, it is possible to use specialised teaching aids (i.e., large-print materials, modified descriptive tools, use of the calculator, writing on computer etc.). The content of education is based on an educational framework program, but some results can be limited according to the abilities of a pupil. At this level of support measures, it is possible to use the 
individual educational program, but it does not include recommendations for adjustments. If needed, there could be used another pedagogical worker such as a teacher assistant and more likely there is used, shared teacher assistant. The shared teacher assistant is assigned to multiple pupils with similar educational problems. However, the shared assistant is limited and more likely they are assigned for one hour per week. Each school that is educating according to the second level of supportive provision is avowed adequate financial support (MICHALÍK; MONČEK; BASLEROVÁ, 2015).

The third level of support measures is characterised by serious intervention into the lessons and organisation of the whole class where the pupil is. These provisions are implemented on the recommendation of the school pedagogical service. The pupil's specialneeds requirements demand noticeable adjustments in the methodology of work, in the organisation and course of education, in the school's educational program and in the pupil's assessment. The educational needs of a pupil are influenced by many factors such as educational disorders, different cultural background and home life, behavioural disorders, severe speech impairment (communication skills), severe speech defects, autistic spectrum disorders, mild intellectual disability, vision and hearing impairment (purblind, hearing loss), physical handicap and unfamiliarity with the language of instruction. All these disabilities and handicaps influence the quality and process of education. During the educational process, the support of the teacher assistant is crucial. The length of using the support measures ranges from months to years. During the education is important to use all accessible supportive provisions including diverse methods, forms, and guidelines. Also, the pupil's abilities and skills have to be respected and considered during the evaluation of the pupil's work. The pupils are educated by their individual educational program which is based on the adjusted educational framework. The content of education can be reduced, and the results of the educational process consider the skills and abilities of the pupil. Along with workbooks special textbooks, teaching, compensatory, and rehabilitation aids are used.

Based on pupils' needs, class size could be reduced. Furthermore, a shared teacher assistant can be used in this class as well. However, the hourly support for a teacher assistant in this class is from 5-8 hours per week. The schools which educate pupils with the need for supportive provisions of the third level can ask for financial support, which allows schools to create study groups of $8-14$ pupils.

Essential adjustments to the education and organisation are then set by the support measures of the fourth level. These measures are implemented on the recommendation of the school pedagogical service. The pupil with this level of measures is educated according to the 
individual educational program (if they are integrated). If the pupil is educated in the school established for pupils with special education needs they are educated according to an adjusted educational school program. Special-pedagogical intervention is important which is more often than at previous levels. In class, specific textbooks are used, and didactic, compensatory and rehabilitation aids as well. Nevertheless, there is a need to adjust the working environment in the classroom. The lesson is taught by a special teacher with the necessary qualification. Usually, the teacher assistant who helps with the self-care and movement of pupils takes part. The support measures of the fourth level are always based on recommendations of schools counselling services. Similar to the previous level, the schools educating pupils with the fourth level of support measures can obtain financial support, which would allow them to create study groups of 6-8 pupils.

The highest level of support measure is the fifth level of supportive provisions. This level involves the major changes in organisation, methodology of education and forms of education as well. The content of education is always modified and adapted with regards to pupil's skills and abilities. The education follows the individual educational plan. The pupil's educational organisation and methodology selection are fully adapted to the abilities, skills, and health conditions of the pupil. The fifth level of support measures is assigned to pupils with the severest level of physical disability or multiple disabilities, which require a great level of support. The health conditions are taken into account when making adjustments to the organisation, content, forms, and methodology of education. The choice of support measures fully respects the pupil's abilities and limits during the educational content and methods, and the assessment of the pupil. The education of pupils with support measures at the fifth level usually involves the adjustment of the working environment (TEPLÁ, 2015). In lessons, it is crucial to use specialised textbooks and other educational materials, as well as the use of financially challenging didactic, rehabilitation and compensation tools. It is always necessary to adjust the working environment in the classroom. If necessary, home-schooling on an individual basis is used. This is provided by school teachers or an STC employee. Like other levels of support measures, the school can obtain financial support which would allow individual education for the pupils for 6-8 hours per week or small classes of up to 6 pupils. Special classes in schools, departments, and study groups can be set up for pupils with intellectual disabilities. Only those pupils for whom the supportive provisions were not sufficient to fulfil the educational opportunities and to exercise the right to education can be included in such a study group. The condition for placement in the group is a written request signed by the legal guardian, the recommendation of school counselling service and 
agreement with the pupil's interest. To create the class, department or study group is necessary to have an agreement from the Ministry of Education, Youth and Sport if the schools are run by the ministry. If the school is run by a region, the creation must be permitted by the regional office.

\section{Other support tools - teacher assistant and personal assistant}

Every pupil should have the right to receive appropriate support accordingly to their talent, skills, and abilities. A pupil with special educational needs is a pupil who needs support to fulfil their potential and rights. One of the support measures is teacher assistant during education in a school. For many pupils, it is a crucial tool for the successful accomplishment of schooling.

A teacher assistant is the second pedagogue in a class and together with special pedagogues and under their guidance the teacher assistant work with a pupil who requires support. Also, the teacher assistant helps with the organization of education thus all pupils can participate. The basic activities of a teacher assistant define public notice no. 27/2016 coll. (CZECH REPUBLIC, 2016). The activities include help with upbringing and education of pupils with specific educational needs, support during adaptation to schools' environment, help during preparation for education and during education. However, during these activities and the teacher assistant's help, the pupil is navigated to be the most independent as possible. Another activity, while an assistant is helping, is self-care activities, or activities organized by the school. A teacher assistant can help with the reconnection of a pupil's family. A teacher assistant has a significant influence on the whole class - social-psychological relations in class, they fulfil the educational needs of all pupils, thus the pupils without special educational needs also. The teacher assistant should have many competencies such as positive relation towards children, ability to communicate with teacher and parents, patience, consistency, will learn from colleagues (srov. 8,12,16,18,19,20).

Pedagogical assistance is different from personal assistance in many aspects. Personal assistance is provided to one concrete client, and it is provided by an organization managed by the Ministry of work and social services based on law no. 108/2006 coll., about social services (CZECH REPUBLIC, 2006; NĚMEC, 2014) Infield of special education, a personal assistant is mainly used for help with the transfer to and from a school, including help with the change of clothes, help with hygiene, providing food and water (UZLOVÁ, 2010). Whether the services of personal assistance should lead to the development of independence 
the cooperation between specialist is crucial. Mainly the cooperation between special pedagogues, psychologists, teacher assistants and personal assistants, doctors, teachers, and others. From a practical perspective is the most comfortable for a pupil, a teacher, and an assistant when the teacher assistant and personal assistant is one person. However, it depends on the legal working relationship. Personal assistants are working as teaching assistants (BAZALOVÁ, 2014). It is important to help financial for securing a personal assistant. However, this does not correspond with free compulsory schooling. In term of education, mainly inclusive education a personal assistant is seen as extra services, whereas a teacher assistant is seen as a crucial tool.

\section{Discussion and conclusion}

The support measures help to meet a pupil's special educational needs. In the context of this paper, the pupils were pupils with intellectual disability. Nowadays work with these pupils is based on the level of support measures, and not on the level of their intellectual disability. The support measures are divided into five categories. The first level of support measures is up to schools and their organization, from the second level the support measures can be placed only with a recommendation from the school's counselling services. The support measures are placed into diverse fields such as organization of education, modification of educational methods and form of work, preparation for education, interventions, tools, adjustments of educational content, classification, health and social support, work class collective, and adjustment of environment. Into the support measures are included education based on the individual educational plan and services of a teacher assistant. The individual educational plan is based on a pupil's knowledge and skills with regards to their intellectual disability. The plan is setting up the goals which a pupil should achieve. Also, it frames the time and content schedule of topics that should be covered. Plus, the plan states methods and form of education and the methods of classification. The teacher assistant supports a pupil with an intellectual disability, they cooperate with teachers and parents.

The motivation or idea for inclusion, so common education of pupils without disabilities and pupils with disabilities is currently the most discussed topic in the Czech's schooling. It is a very actual, and modern theme that still needs to be discussed and highlighted. The idea of inclusive education is to educate all pupils together without any differences. Since 1st September 2016, inclusive education has been implemented in real 
schools, for now only in primary schools. This change has forced some legal changes. However, it brought more changes in practice. It involves more optional education for pedagogues who might have problems implementing inclusive education into practice because they do not know or might do not know how to use legal news in practice.

Currently, Czech's education is trying to integrate pupils with disabilities into mainstream schools. However, successful integration involves the preparation of all participants. Nevertheless, not everyone is excised about inclusive education. There are parents who prefer to educate their child with a disability in a specific primary school. They believe that their child is receiving all possible support and development of all personal parts in there. Therefore, they are not following the inclusive trend in primary schools. Inclusive education is stated in law, so all children with disabilities have the best possible option for education and successful life in society.

Throughout respecting all differences of all pupils, the inclusive education can be seen as kind of successful education which removes discrimination and enriches life quality of all participants.

\section{REFERENCES}

BARTOŇOVÁ, M.; VITKOVA. The intervention in inclusive education of children, pupils, and students with health disability and their work placement. Brno: Masaryk University, 2013.

BARTOŇOVÁ, M.; VÍTKOVÁ, M. Common education aimed at enhancing the competences of teachers and students in the inclusive school environment. Brno: Masaryk University, 2017.

BAZALOVÁ, B. A Child with intellectual disability and Support of their development. Prague: Portal, 2014.

BEDNOVÁ, P.; ZİKL, P. Child with intellectual disability in school. Prague; Grada, 2012.

CLOUGH, P.; CORBETT J. Theories of Inclusive Education. London: Paul Chapman Publishing, 2005.

CZECH REPUBLIC. Law number 561/2004 collection. Law on preschool, primary, high school, higher specified and other education (school act). 2004.

CZECH REPUBLIC. Law number 108/2006 collection. Social services. 2006.

CZECH REPUBLIC. Law number 82/2015 collection. Law, changing the law number $561 / 2004$ collection, about preschool, primary, high school, higher specified and other education (school act). 2015. 
CZECH REPUBLIC. Public notice number 27/2016 collection. Public notice about education of pupils with special education needs and talented pupils. 2016.

HÁJKOVÁ, V.; STRNADOVÁ, I. Inclusive education: theory and practice. Prague: Grada, 2010 .

MİCHALÍK, J. Parents and child with health disability (not only) at primary school. Pardubice: Studio Press Ltd., 2013.

MICHALÍK, J.; FELCMANOVÁ, L.; BASLEROVÁ, P. The Catalogue support measures: basic part for pupils with needs of support while education due to their health or social disadvantage. Olomouc: University of Palacky in Olomouc, 2015.

MINISTERSTVO ŠKOLSTVÍ. Mládeže a tělovýchovy České republiky. 2020.

MORÁVKOVÁ VEJROCHOVÁ, M. The standard of teacher assistant's work. Olomouc: University of Palacky in Olomouc, 2015.

NĚMEC, Z. The assistant services in education of pupils with social disadvantage. Prague: Nova Skola, 2014.

STÁREK, L. School interacting with the pupil's family. EEO, v. 20, n. 5, p. 3778-3789, 2021.

TEPLÁ, M. The teacher assistant: how implement teacher assistant effectively in schools. Prague: Verlag Dashöfer, 2015.

UZLOVÁ, I. The assistant services for people with disabilities and disadvantages: the practical guidance for personal and pedagogical assistants. Prague: Portal, 2010.

VÁGNEROVÁ, M. Developmental psychology: childhood, adulthood, senescence. Prague: Portal, 2000.

VALENTA, M. et al. The catalogue support measures: for pupils with needs of support while education due to intellectual disability or weaker cognitive development. University of Palacky in Olomouc, 2015.

VÍŠEK, J.; KROUPA, P. Modern legal states, law stability, and legal security. In:

KRZYZANKOVA, K. Z. (Ed.). Law as multidimensional phenomena: Compliment to Ales Gerloch to 65th birthday. Pilsen: Vydavatelství a nakladatelství Aleš Čeněk, 2020.

VÍTKOVÁ, M. Integrative special education. Integration of school and social. Brno: Paido; 2004.

ZPĚVÁK, A. The current aspects of entrepreneurial activities in social services. In Quo Vadis, social work in Czech Republic II. Prague: The Institute for Public services; 2019. 


\section{How to reference this article}

STÁREK, L.; KLUGEROVÁ, J.; AND KOCUROVÁ, M. Optıons of support for primary schools' pupils with mental disabilities with highlights on social and educational aspects in the Czech Republic. Revista online de Política e Gestão Educacional, Araraquara, v. 25, n. 3, p. 2552-2566, Sep./Dec. 2021. e-ISSN: 1519-9029. DOI: https://doi.org/10.22633/rpge.v25i2.15841

Submitted: 10/09/2021

Required revisions: 13/10/2021

Approved: $11 / 11 / 2021$

Published: 08/12/2021 